\title{
Changes and new features for our readers and authors
}

\author{
Robert C. Griggs, MD, Editor-in-Chief; and Kathleen M. Pieper, Online Managing Editor
}

Changes in Editorial Office. We welcome Garrett $\mathrm{H}$. Riggs, $\mathrm{MD}, \mathrm{PhD}$, as an Associate Editor for Neurology. Dr. Riggs was appointed Book Review Editor of Neurology last year and continues with that responsibility. He has a career focus on cognitive and behavioral neurology at the University of Rochester. There is a new editor for the Humanities section of Neurology. Michael H. Brooke, MD, FAAN, took over as editor of this section effective July 1 . He has renamed the section "Reflections." We thank Dr. David Goldblatt, our retiring Nisus editor, for his dedication in developing this section and making it a success. We welcome new section co-editors for our online CME section: Paul Schulz, MD, from Baylor in Houston and Steve Lewis, MD, from RushPresbyterian in Chicago. We thank outgoing CME Editor J. Clay Goodman for initiating the CME section and congratulate him on its success and the tremendous growth of its use.

Manuscripts. The number of manuscripts we receive continues to increase every year. Neurology received 7\% more manuscripts in 2004 than 2003 and we have already seen an increase in submissions for the first quarter of 2005 from the same quarter in 2004 - on a pace for receiving over 4,100 manuscripts in 2005. International submissions account for over $65 \%$ of all submissions. Web access of www. neurology.org has also increased steadily: readership has increased fivefold since 2000. This access includes full text, abstracts, searches, Table of Contents, and the home page.

Changes and new features for our readers and authors. Expedited E-pub. Our new Expedited E-pub section launched Thursday, April 7, with six articles. Users can find the link at the top of our home page (www.neurology.org). Twenty-five percent of content, fully copyedited and author-approved, will be posted online 31 days after receipt by the publisher. Postings will be done every Wednesday. Abstracts and PDFs are immediately available to users.

PDA download. We will soon have a link on our home page that will provide the following PDA downloads: Table of Contents, Resident and Fellow Page, and Patient Page.
Enhanced PDFs. We will soon launch this feature in the online version of Neurology. On downloaded PDFs of Neurology articles, readers can find other articles that have cited the downloaded article, go-with editorials, Correspondence relating to the article, and other interesting features. The PDF is updated on a regular basis to ensure its accuracy and timeliness.

PowerPoint download. Neurology online will soon allow users to directly download figures and tables to PowerPoint presentations. The downloaded figure will include the Neurology citation for the article. We expect that this will be helpful material for teaching and presentations.

Change in author disclosure forms and conflict of interest policy. Corresponding authors are now required to list a disclosure section on the title page of their submitted manuscript. If there are no disclosures to mention, the author will be asked to state "The authors have reported no conflicts of interest." If there are pertinent disclosures to be made, the author must state each disclosure for each author including relationship with industry in the form of sponsorship, grants, employ, equity, expert testimony, or patent royalties.

Open access. Our copyright form, required for all accepted manuscripts, has been amended to reflect the recent NIH decision that provides open access for NIH-funded research. The new paragraph states:

AEI authorizes NIH-funded investigators to submit an electronic version of the final, accepted manuscript to the NIH for publication on PubMedCentral no earlier than twelve months after the print or online publication in Neurology. The authorization is a nonexclusive license only for the purpose stated in the NIH Public Access Policy (see 70 Federal Register 6899-6900 dated February 9, 2005); AEI reserves all rights not specifically granted in this nonexclusive license.

International editions. We currently have Italian, Polish, and Japanese editions of the Journal. Chinese (Mandarin), Turkish, and Hungarian editions have also been approved. The Polish edition Editors Anna Czlonkowska (Warsaw) and Zbigniew Wszolek (Jacksonville) have appointed an editorial board and have begun publishing Polish commentary on certain Neurology articles. We expect that other 
international editions will follow their lead. We will publish the foreign language versions of articles on the Web site as a link within the main article.

Online activation. We encourage print readers to activate their online subscriptions. Users can access Neurology and select the "login instructions" link provided on the Help screen. This will lead users to a step-by-step activation process. The online journal includes full text (PDF and HTML formats) of articles from 1999 forward, links to PubMed, and extensive search capabilities. It also includes features not available in the print version, including Expedited E-pub articles, rapidly posted Correspondence, CME,
Video, Patient Page, Resident and Fellow Page, and Supplemental Data.

Production. Finally, we want to express our appreciation to the production team at Lippincott Williams \& Wilkins for their high-quality work and collegial approach: David Marshall, new (since November 2004) Senior Publisher; Kevin Fitzpatrick, Vice-President Business Development; Alexandra Lazerow and Christine Jennings, Senior Production Editors; Erin Romanski, Production Editor; Angela Hopkins, Production Associate; and Ray Thibodeau, Vice-President Advertising Sales. 


\section{Neurology}

\section{Changes and new features for our readers and authors \\ Robert C. Griggs and Kathleen M. Pieper \\ Neurology 2005;65;4-5 \\ DOI 10.1212/01.wnl.0000172047.65804.5e}

\section{This information is current as of July 11, 2005}

\section{Updated Information \&}

Services

Permissions \& Licensing

Reprints including high resolution figures, can be found at: http://n.neurology.org/content/65/1/4.full

Information about reproducing this article in parts (figures,tables) or in its entirety can be found online at:

http://www.neurology.org/about/about_the_journal\#permissions

Information about ordering reprints can be found online:

http://n.neurology.org/subscribers/advertise

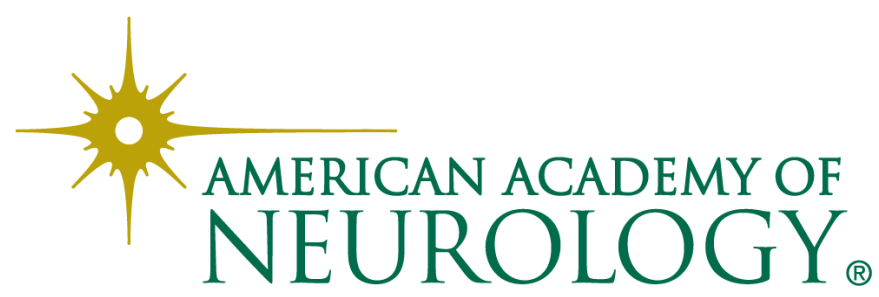

